\title{
Microbial Interconversion of Alkanes to Electricity
}

\author{
Silvan Scheller* \\ Department of Bioproducts and Biosystems, Aalto University, Espoo, Finland
}

OPEN ACCESS

Edited by:

Deepak Pant

Flemish Institute for Technological

Research, Belgium

Reviewed by:

loannis Andrea leropoulos, University of the West of England,

United Kingdom

Matteo Grattieri,

University of Utah, United States

*Correspondence:

Silvan Scheller

silvan.scheller@aalto.fi

Specialty section:

This article was submitted to

Bioenergy and Biofuels,

a section of the journal

Frontiers in Energy Research

Received: 23 May 2018

Accepted: 18 October 2018

Published: 05 November 2018

Citation:

Scheller S (2018) Microbial

Interconversion of Alkanes to

Electricity. Front. Energy Res. 6:117.

doi: 10.3389/fenrg.2018.00117
Electricity from fuels can be produced via 2 fundamentally different methods: By burning them to spin generators, or by direct abstraction of electrons at catalysts. The future is the flame-free production of electricity via catalysis, whereby the maximal theoretical yield scales inversely proportional to the process temperature. Low temperature fuel cells are thus needed, but they are not available for hydrocarbons due to the recalcitrant $\mathrm{C}-\mathrm{H}$ bonds present in alkanes. Fuel cells for alkanes typically require process temperatures higher than $600^{\circ} \mathrm{C}$. The microbial pathway of anaerobic alkane oxidation, on the other side, converts alkanes reversibly to single electrons and $\mathrm{CO}_{2}$ at temperatures as low as $4^{\circ} \mathrm{C}$. In this perspective, I suggest to utilize this microbial metabolism for catalytic alkane oxidation at low temperatures, in order to convert alkanes to electricity with possibly higher thermodynamic efficiencies as current technologies. Alkane oxidation is partitioned into a biocatalytic (microbial) step to cleave the $\mathrm{C}-\mathrm{H}$ bonds, and into an electrochemical step for harvest of electricity. In the biocatalytic step, the alkane is oxidized to $\mathrm{CO}_{2}$ and the resulting electrons are loaded onto an electron carrier. Electricity is then generated from the electron-carrier via fuel cells. Due to the intrinsic reversibility of the biochemical pathway, the whole process may be reversed to convert excess electricity (e.g., from solar or wind) with $\mathrm{CO}_{2}$ to alkanes, which is particularly interesting for the alkanes ethane, propane or butane that are easily liquefiable and storable.

Keywords: archaea and bacteria, biocatalyis, fuel conversion efficiency, electron transfer (redox reactions), microbial fuel cells (MFC), sustainable electricity production, power to gas, anaerobic oxidation of methane (AOM)

\section{GENERATION OF ELECTRICITY FROM FUELS}

Our society got heavily dependent on un-interrupted availability of electricity, our most versatile form of energy. Production of electricity from fuels can be performed via 2 fundamentally different methods. The first and currently dominating procedure is to burn the fuel and spin generators that produce electricity. The second method, discussed in this document, relies on catalytic oxidation of the fuel thereby directly abstracting electrons as carried out in fuel cells. The thermodynamic efficiency of catalytic electricity production scales inversely with temperature: The lower the process temperature, the higher the maximum amount of electricity that can be extracted. For hydrocarbons, fuel cells typically operate at temperatures above $600^{\circ} \mathrm{C}$ (O'Hayre et al., 2016). Low temperature fuel cells $\left(\mathrm{T}<100^{\circ} \mathrm{C}\right)$ exist only for hydrogen and for a few uncommon fuels, such as methanol or formic acid (Gold, 2012).

In this perspective, I discuss a possible solution for catalytic electricity production from alkanes at cold temperatures, using the recently discovered process of microbial alkane oxidation with release of single electrons. The system proposed is a derivative of a mediated microbial fuel cell. Toward the end of this document, I describe how this biochemistry can possibly be reversed to convert excess electricity (e.g., from wind or sun) to alkanes as storage compounds. 


\section{MICROBIAL ELECTRICITY PRODUCTION FROM ALKANES}

Certain microbes are capable of producing or taking up single electrons (Lovley, 2012). Recently, microbes of the domain archaea from the deep-sea (Figure 1A) have been reported to make a living by oxidizing methane to $\mathrm{CO}_{2}$, concomitant with transfer of electrons via electrical conductance to partner microbes that reduce sulfate (McGlynn et al., 2015; Wegener et al., 2015). Shortly after, related microbes were described carrying out the analogous reaction for the higher alkanes propane and butane (Laso-Pérez et al., 2016). In the microbial communities responsible for this process, the overall reaction of alkane oxidation with sulfate as the oxidant is partitioned such that each type of microbes carries out one half reaction (Figure 1B).

The microbial setup resembles a fuel cell in which archaea are the anode (red) and bacteria the cathode (green). In microbiology, this type of syntrophy is called direct-interspecieselectron transfer (Lovley, 2017). Electrical current is enabled by conductive biological structures such as multi-heme-c-type cytochromes (Pirbadian and El-Naggar, 2012), or different types of conductive "nano-wires" (Gorby et al., 2006; Wegener et al., 2015). Reported half reactions of alkane oxidation with release of single electrons are equations 1, 3 and 4:

(1) $\mathrm{CH}_{4}+2 \mathrm{H}_{2} \mathrm{O}=\mathrm{CO}_{2}+8 \mathrm{e}^{-}+8 \mathrm{H}^{+}\left(\mathrm{E}^{\circ \prime}=-245 \mathrm{mV}\right)$

(2) $\mathrm{C}_{2} \mathrm{H}_{6}+4 \mathrm{H}_{2} \mathrm{O}=2 \mathrm{CO}_{2}+14 \mathrm{e}^{-}+14 \mathrm{H}^{+}\left(\mathrm{E}^{\circ \prime}=-272 \mathrm{mV}\right)$

(3) $\mathrm{C}_{3} \mathrm{H}_{8}+6 \mathrm{H}_{2} \mathrm{O}=3 \mathrm{CO}_{2}+20 \mathrm{e}^{-}+20 \mathrm{H}^{+}\left(\mathrm{E}^{\circ \prime}=-278 \mathrm{mV}\right)$

(4) $\mathrm{C}_{4} \mathrm{H}_{10}+8 \mathrm{H}_{2} \mathrm{O}=4 \mathrm{CO}_{2}+26 \mathrm{e}^{-}+26 \mathrm{H}^{+}\left(\mathrm{E}^{\circ \prime}=-280\right.$ $\mathrm{mV}$ )

These reactions are the same as at anodes of solid oxide fuel cells, but they proceed at $4^{\circ} \mathrm{C}$ instead of at $>600^{\circ} \mathrm{C}$.

\section{APPLICATION OF MICROBIAL ELECTRICITY PRODUCTION FROM ALKANES}

To harvest the biochemically produced electrons, the bacteria that naturally consume them (Figure 1B, green) need to be replaced. The classical way is to replace the bacteria by a fuel-cell cathode in one device (bio fuel cell), in which the compartments are separated by an ion-conductive membrane (Logan et al., 2006; McAnulty et al., 2017; Schröder and Harnisch, 2017). An alternative approach is replacing the bacteria by an auxiliary redox reaction, which is described here in more detail. Such a system corresponds to a mediated microbial fuel cell, whereby microbes are used to convert the fuel into a compound that can be easily utilized in a conventional fuel cell. A soluble electron carrier (Fultz and Durst, 1982) connects the biological step of alkane oxidation with the electrochemical step of oxygen reduction, allowing the 2 half-reactions to be spatially separated. The chemically challenging step of alkane oxidation and transfer of the electron to a soluble electron carrier has been achieved for the alkane methane (Scheller et al.,
2016) utilizing the electron carrier $\mathrm{Q}=9,10$-anthraquinone-2,6disulfonate, AQDS, $\mathrm{E}^{\circ \prime}=-186 \mathrm{mV}$, as illustrated in Figure 1C. This reaction means that the fuel methane is converted to the fuel $\mathrm{QH}_{2}$, from which electricity is harvested by a fuel cell. The homologous biochemical reaction should be possible for higher alkanes as well, but such experiments have not been reported to date.

\section{EXAMPLE OF A TWO-STEP PROCESS FOR METHANE TO ELECTRICITY}

The 2-step set-up presented here has the advantage that microbes are not directly connected to the electrode (easier to implement system and to exchange the microbes), but the disadvantage that some amount of additional energy is utilized to pump the mediator from the bioreactor to the fuel cell. A separated 2-step process is described here and not an unmediated microbial fuel cell, because there is proof of principle for the reaction shown in Figure 1C, unlike for such microbes directly attached to an electrode.

The overall process of methane oxidation with air, equation 5 $\left(\mathrm{E}^{\circ \prime}=-0.245 \mathrm{~V}\right.$ for $\mathrm{CH}_{4} / \mathrm{CO}_{2}$ and $\mathrm{E}^{\circ \prime}=0.815 \mathrm{~V}$ for $\left.\mathrm{H}_{2} \mathrm{O} / \mathrm{O}_{2}\right)$, is divided into a biochemical reaction (equation 6) and an electrochemical reaction (equation 7).

(5) $\mathrm{CH}_{4}+2 \mathrm{O}_{2}=\mathrm{CO}_{2}+2 \mathrm{H}_{2} \mathrm{O}\left(\Delta \mathrm{E}^{\circ \prime}=1.060 \mathrm{~V}\right)$

(6) $\mathrm{CH}_{4}+4 \mathrm{Q}+2 \mathrm{H}_{2} \mathrm{O}=\mathrm{CO}_{2}+4 \mathrm{QH}_{2}\left(\Delta \mathrm{E}^{\circ \prime}=0.059 \mathrm{~V}\right.$, for $\mathrm{Q}=\mathrm{AQDS})$

(7) $4 \mathrm{QH}_{2}+2 \mathrm{O}_{2}=4 \mathrm{Q}+4 \mathrm{H}_{2} \mathrm{O}\left(\Delta \mathrm{E}^{\circ \prime}=1.001 \mathrm{~V}\right.$, for $\mathrm{Q}=$ AQDS)

In the biochemical reaction (equation 6), the energy carrier methane is converted into the energy carrier $\mathrm{QH}_{2}$. Proof of concept for the biochemical reaction (equation 6) has been obtained with environmental microbes in batch mode at $1 \mathrm{ml}$ scale (Scheller et al., 2016). From the energy carrier $\mathrm{QH}_{2}$, electricity can then be harvested (equation 7), similar to flowbatteries that use the same electron carrier but $\mathrm{Br}_{2} / \mathrm{HBr}$ at the cathode (Huskinson et al., 2014).

The overall set up may be realized by feeding a bioreactor with medium that contains dissolved methane and the soluble electron carrier (Figure 2). In this set-up, which has not yet been done in large scale due to lack of the biocatalyst (see "research needs"), the microbes are immobilized in a packed bed reactor. The outlet of the bioreactor contains the soluble reduced electron carrier $\left(\mathrm{QH}_{2}\right)$ and dissolved $\mathrm{CO}_{2}$. The $\mathrm{CO}_{2}$ is separated and used for other purposes or stored, and the reduced electron-acceptor enters a fuel cell operating with air in the cathode.

\section{ASSESSMENT OF THERMODYNAMIC EFFICIENCY FOR METHANE TO ELECTRICITY}

The overall thermodynamic efficiency depends on the maximal theoretical efficiency (see part A), and on losses (see parts B-D) as described below for the alkane methane. 

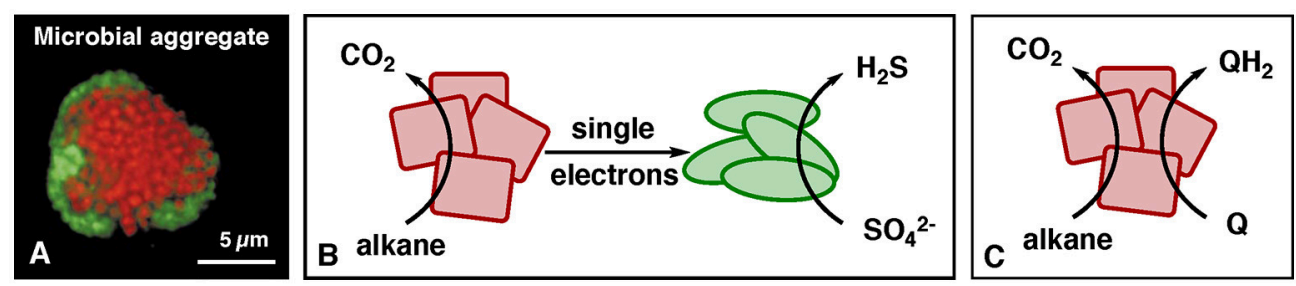

FIGURE 1 | Alkane oxidation by environmental microbes. (A) Microscopy picture of a microbial aggregate that performs methane oxidation coupled to sulfate reduction [from Reference (Boetius et al., 2000)]. Red microbes = methane-oxidizing archaea, green microbes = sulfate-reducing bacteria. (B) Process of alkane oxidation by environmental archaea (red) with electron transfer to sulfate-reducing partner bacteria (green). (C) Coupling of alkane oxidation with the reduction of synthetic electron carriers $(Q)$, as demonstrated for the alkane methane (Scheller et al., 2016).
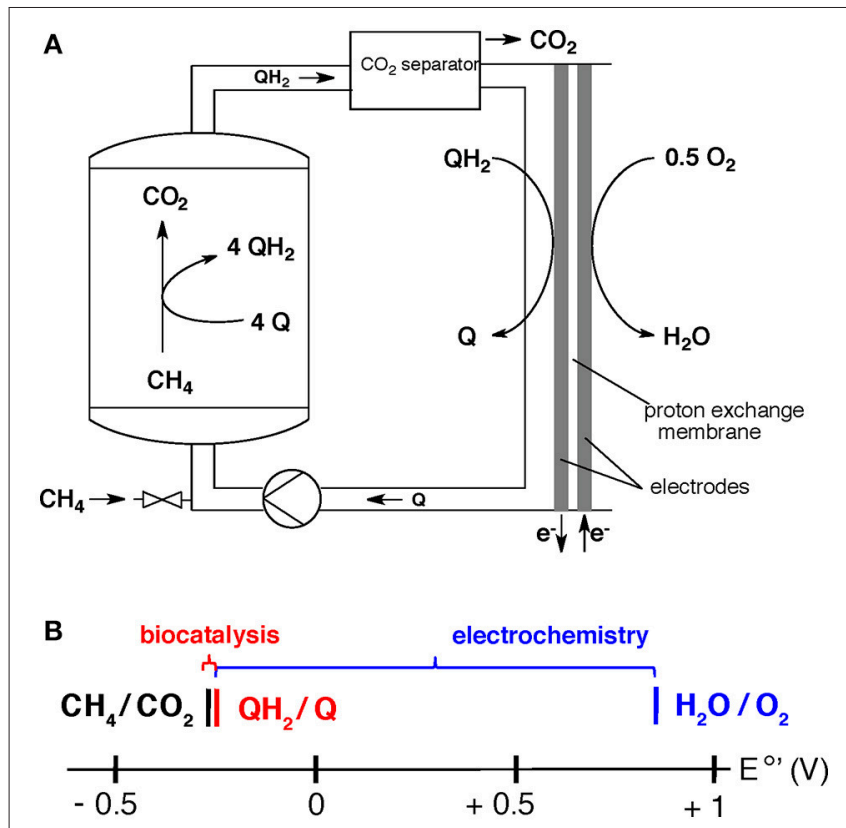

FIGURE 2 | (A) Proposed system for electricity generation from methane via a two-step process involving biocatalysis (left side) and electrochemistry (right side) (Scheller et al., 2018). (B) Division of energy (redox-potential difference) from methane oxidation with air (equation 5) into a biochemical step of fuel conversion (red, equation 6), followed by an electrochemical step of electricity harvest (blue, equation 7).

\section{A) Theoretical maximum of overall process}

The maximal theoretical efficiency (methane oxidation with air) corresponds to $\Delta \mathrm{G} / \Delta \mathrm{H}$, whereby $\Delta \mathrm{G}$ depends on the process temperature according to equation 8 :

(8) Maximal extractable electrical energy $=\Delta \mathrm{G}=\Delta \mathrm{H}-\mathrm{T} \Delta \mathrm{S}$

whereby $\Delta \mathrm{H}$ is the enthalpy of the process $(\Delta \mathrm{H}=-890.3 \mathrm{~kJ}$ $\left.\mathrm{mol}^{-1}\right)$ and $\Delta \mathrm{S}$ is the reaction entropy $\left(-242.4 \mathrm{~J} \mathrm{~mol}^{-1} \mathrm{~K}^{-1}\right)$ and $\mathrm{T}$ is the absolute temperature.

As $\Delta S$ is negative, more electricity can be harvested at lower temperature ( $\Delta \mathrm{G}$ is more negative). The same relation applies for higher hydrocarbons. For the lower temperature range of current solid oxide fuel cells $\left(\mathrm{T}=600^{\circ} \mathrm{C}\right)$, the maximal thermodynamic efficiency $(\Delta \mathrm{G} / \Delta \mathrm{H})$ is $76 \%$ (equation 8 with $\mathrm{T}=873 \mathrm{~K}$ ). At room temperature, however, the maximal thermodynamic efficiency would be $92 \%$ (equation 8 with $\mathrm{T}=298 \mathrm{~K}$ ).

B) Thermodynamic losses due to two-step process

In the 2-step set-up discussed here, electricity is produced only from the electrochemical process (equation 7), which means that the difference in the redox potential of equation 6 cannot be utilized.

Equation 6 corresponds to $\Delta \mathrm{E}^{\circ \prime}=0.059 \mathrm{~V}(5.6 \%$ of total energy) for $\mathrm{Q}=\mathrm{AQDS}$ and standard conditions. In environmental microbes carrying out methane oxidation with sulfate in situ, equation 6 corresponds only to $\Delta \mathrm{E}<0.026 \mathrm{~V}(\Delta \mathrm{G}$ for half reaction is between $-5 \mathrm{~kJ} \mathrm{~mol}^{-1}$ and $-20 \mathrm{~kJ} \mathrm{~mol}^{-1}$ ) (Knittel and Boetius, 2009).

If an electron carrier $\mathrm{Q}$ with a slightly more negative redox potential would be used ( $\Delta \mathrm{E}=0.026 \mathrm{~V}$ for equation 6 ), as in environmental microbes, only $2.5 \%$ of the energy would be "lost" due to biocatalysis.

C) Thermodynamic efficiency of fuel cell

The fuel cell will be the main contributor to losses in efficiency in the operating system. The main reason is the high overpotential at the oxygen-reducing cathode, which depends on the current per area utilized. Such polarization effects can add up to $0.5 \mathrm{~V}$ under maximum power transfer (corresponding to a loss of up to $50 \%$ ), a major issue that remains to be resolved. The anode process involving the artificial electron carrier is associated with low overpotentials, because compounds such as AQDS have excellent electrochemical properties (Rosso et al., 2004). For the calculation here, an efficiency of $70 \%$ is assumed.

\section{D) Additional losses}

Additional losses in the overall efficiency involve pumping the electron carrier between bioreactor and fuel cell, replacement of microbes, production costs, pressurizing methane, removal of $\mathrm{CO}_{2}$, heat exchange. Those depend on the engineering and on the scaling of the overall system.

\section{E) Overall assessment}

The overall efficiency is the product of (A) thermodynamic efficiency 92\%, (B) contribution to fuel cell: $94.4-97.5 \%$, (C) 
efficiency of fuel cell 50-70\% (with current technologies), and (D) additional losses e.g., 90\%. These numbers yield an overall efficiency of $39-57 \%$.

Thus, the main losses come from the overpotential at the cathode, a general challenge in current fuel-cell research, for which solutions are needed.

\section{ASSESSMENT OF KINETICS FOR METHANE TO ELECTRICITY}

Up to date, only uncultured microbes from the environment are available for the biocatalysis of alkane to electricity conversion (see section "research needs"). Enrichment cultures of such microbes from the environment maintained at $12^{\circ} \mathrm{C}$ with 14 bar $\mathrm{CH}_{4}$ catalyze specific methane oxidation rates of $1-20 \mathrm{mmol}$ day $^{-1} \mathrm{~g}^{-1}$ cell dry mass (Knittel and Boetius, 2009), assuming equal amounts of archaea and bacteria in the community. This converts to 2.3-46 $\mathrm{mmol} \mathrm{CH}_{4}$ per second per $\mathrm{m}^{3}$ of living archaeal biomass (assuming dry weight $=20 \%$ of wet weight and density $=1 \mathrm{~g} \mathrm{ml}^{-1}$ ).

If those environmental microbes would be used for the setup described in Figure 2, $1 \mathrm{~m}^{3}$ archaea cells would be required to produce an electric output of $1.2-25 \mathrm{~kW}$, assuming $70 \%$ efficiency of the fuel cell (calculation: Power $=70 \% *$ rate $^{*} \mathrm{n} * \mathrm{~F} * \Delta \mathrm{E}$, with rate $=2.3-46 \mathrm{mmol} \mathrm{CH}_{4}$ per second, $n=8, \mathrm{~F}=$ Faraday constant and $\Delta \mathrm{E}=1.001 \mathrm{~V}$ for equation 7$)$. To obtain faster rates, microbes need to be designed that possess a faster catabolism (see "research needs").

Non-biochemical kinetic limitations may arise from gas exchange to microbes or dissolution of methane, and from transfer of protons through fuel cell membrane. The electron acceptor AQDS has excellent electrochemical redox-kinetics (Rosso et al., 2004), but the oxygen reduction may be limiting, especially when the system is trimmed for high thermodynamic yields (i.e., lower current per area). The solubility of methane is about $144 \mathrm{mM}$ under predicted reactor conditions [200 bar, $\mathrm{T}=$ $37^{\circ} \mathrm{C}, 1.0$ salt concentration, according to reference (Duan and Mao, 2006)]. Higher alkanes would liquefy at higher pressures and are therefore more applicable for the reverse process.

\section{BIOCHEMISTRY OF MICROBIAL ALKANE OXIDATION AND FORMATION}

The carbon metabolism from methane to $\mathrm{CO}_{2}$ is congruent to that of biological methane formation from $\mathrm{CO}_{2}$, but operating in reverse direction (Hallam et al., 2004). This bi-directionality is possible because the pathway proceeds close to the thermodynamic equilibrium. Depending on the directionality, the microbial metabolism is wired differently to allow the cells to grow (Thauer et al., 2008), implying that one type of organism appears to only carry out one direction of the pathway (McGlynn, 2017; Timmers et al., 2017).

The archaeal biochemistry of converting higher alkanes to $\mathrm{CO}_{2}$ is initiated by homologous enzymes as for methane (LasoPérez et al., 2016), in which the alkane is reversibly converted to an alkyl-sulfide. The downstream pathway from the alkysulfide to $\mathrm{CO}_{2}$ has not yet been fully elucidated. For the reverse reaction (conversion of $\mathrm{CO}_{2}$ to higher alkanes), no microbes producing ethane, propane or butane are reported. According to thermodynamics, however, such metabolisms are feasible in both directions, and corresponding microbes may be genetically designed (see "research needs").

\section{SYSTEM FOR ELECTRICITY TO ALKANES}

For the alkane methane, bioelectrochemical gas generation is a vibrant research topic (Geppert et al., 2016). Current technologies utilize "classical" methanogens (Enzmann et al., 2018) as catalysts that are not adapted to carry out direct electron transfer, which might be the reason for the high overpotentials in those reactions (Geppert et al., 2016), or that they just apparently carry out direct extracellular electron transfer (Deutzmanna et al., 2015). For higher efficiencies, a methanogen able of taking up electrons directly from an electrode, or from a reduced soluble electron carrier is needed (see "research needs"). With a reduced electron carrier, the same design as in Figure 2 can be chosen, but all the reactions operate in reverse direction (all arrows reversed), and the carrier " $\mathrm{QH}_{2}$ " requires $\mathrm{E}^{\circ \prime}=$ ca. $-304 \mathrm{mV}$ (in order to provide the same potential difference, $59 \mathrm{mV}$, for the microbes as for methane oxidation).

The advantage of such a system over just making methane from electricity-derived hydrogen is that the soluble electron donor can be produced with higher efficiency than currently possible for hydrogen generation. Modifying the microbes to produce higher alkanes (see "research needs") is an attractive way to interconvert excess electricity (e.g., from wind or sun) with $\mathrm{CO}_{2}$ to liquefiable alkanes for storage.

\section{RESEARCH NEEDS FOR ALKANES TO ELECTRICITY}

Implementation of the technology is currently hampered by the unavailability of the required microbes that are the biocatalyst. Before engineering of the application can be started, substantial research on microbial physiology is needed, including elucidation of the currently unknown biochemistry for the metabolism of higher alkanes. Enrichments of environmental microbes (e.g., of iron-reducing methanotrophs Cai et al., 2018) are under way that may be used for the system. A promising alternative to access the desired microbes is to genetic engineer them. Successful design of the microbes requires knowledge about the detailed physiology of the environmental microbes, which needs to be elucidated. With this knowledge, model microbes that grow fast on alternative substrates (e.g., on alcohols, such as methanol for the organism $M$. acetivorans) can be equipped with the metabolic capability to carry out alkane oxidation coupled to the production of $\mathrm{QH}_{2}$. Via genetic engineering, the microbes can be tuned for faster performance to make the technology more competitive, because in the environmental system the alkane-oxidizers have only about $\Delta \mathrm{G}=-5$ to $-20 \mathrm{~kJ} \mathrm{~mol}^{-1}$ energy to drive the metabolism (Knittel and Boetius, 2009), but in the engineered system, more 
energy can be attributed to biocatalysis. If the metabolism would be fully limited by reaction thermodynamics, every $5.7 \mathrm{~kJ} \mathrm{~mol}^{-1}$ in additional energy attributed to the metabolism can speed up the reaction up to a factor of 10 , thus substantial rate acceleration may be possible for the electron carrier discussed (equation 6), for which $\Delta \mathrm{G}^{\circ \prime}$ is $-46 \mathrm{~kJ} \mathrm{~mol}^{-1}$. The reality in environmental microbes is probably a mixture of thermodynamic and kinetic limitations, whereby the main contribution for the kinetic limitation clearly comes from alkane activation by the enzyme methyl-coenzyme M reductase (Scheller et al., 2010; Grisewood et al., 2018). The process temperature can be increased to $37^{\circ} \mathrm{C}$ [using the model organisms M. acetivorans (Nayak and Metcalf, 2017) or M. maripaludis (Goyal et al., 2016)], resulting in a 510 fold rate increase $\left[2-3\right.$ fold per $\Delta \mathrm{T}=10^{\circ} \mathrm{C}$, as common for microbes (Pachepsky et al., 2014)], and the methane pressure can be increased by a factor of 10 . Prediction of the rate enhancement by those modifications is difficult (Ritchie, 2018) and thus needs the modifications to be carried out experimentally. If a rateacceleration by a factor of $100-1000$ is achieved via optimized microbes, the installation volumes of the final industrial set up become industrially applicable.

\section{RESEARCH NEEDS FOR ELECTRICITY TO ALKANES}

To allow methane formation from electricity, the genes for hydrogenases in methanogens (responsible for electron transfer from $\mathrm{H}_{2}$ ) need to be replaced by those encoding for multi-heme $c$-type cytochromes (to allow electron uptake). An alternative strategy could be reversing a methanotroph to generate methane, as they evolved for efficient electron transfer. Changing the primary metabolism requires changing the way cells conserve energy, which is in the beginning of being understood (McGlynn, 2017; Yan et al., 2018). Engineering of microbes to convert

\section{REFERENCES}

Boetius, A., Ravenschlag, K., Schubert, C. J., Rickert, D., Widdel, F., Gieseke, A., et al., (2000).A marine microbial consortium apparently mediating anaerobic oxidation of methane. Nat. 407, 623-626. doi: 10.1038/35036572

Cai, C., Leu, A. O., Xie, G.-J., Guo, J., Feng, Y., Zhao, J.-X., et al. (2018). A methanotrophic archaeon couples anaerobic oxidation of methane to $\mathrm{Fe}(\mathrm{III})$ reduction. ISME J. 12, 1929-1939. doi: 10.1038/s41396-018-0109-x

Deutzmanna, J. S., Sahina, M., and Spormanna, A. M. (2015). Extracellular enzymes facilitate electron uptake in biocorrosion and bioelectrosynthesis. MBio 6, 1-8. doi: 10.1128/mBio.00496-15

Duan, Z., and Mao, S. (2006). A thermodynamic model for calculating methane solubility, density and gas phase composition of methane-bearing aqueous fluids from 273 to $523 \mathrm{~K}$ and from 1 to 2000 bar. Geochim. Cosmochim. Acta 70, 3369-3386. doi: 10.1016/j.gca.2006.03.018

Enzmann, F., Mayer, F., Rother, M., and Holtmann, D. (2018). Methanogens: biochemical background and biotechnological applications. AMB Express 8, 1-22. doi: 10.1186/s13568-017-0531-x

Fultz, M. L., and Durst, R. A. (1982). Mediator compounds for the electrochemical study of biological redox systems - a compilation. Anal. Chim. Acta 140, 1-18. doi: 10.1016/S0003-2670(01)95447-9

Geppert, F., Liu, D., van Eerten-Jansen, M., Weidner, E., Buisman, C., Ter Heijne, A., et al. (2016). Bioelectrochemical power-to-gas: state of the art and future perspectives. Trends Biotechnol. 34, 879-894. doi: 10.1016/j.tibtech.2016.08.010 electricity to higher alkanes, first needs the elucidation of the currently unknown biochemical steps involved, before genetic engineering can be started. For all processes, understanding and genetic engineering of enzymes related to direct electron transfer (multi-heme $c$-type cytochromes) are crucial but currently at a very early stage of research.

\section{CONCLUSIONS}

The technology of microbial alkane to electricity interconversion is in a low technology readiness level. Current attempts of electricity to methane conversion with classical methanogens suffer from high overpotentials that are due to inefficient uptake of electrons by the methanogens involved.

By designing microbes with the desired metabolism (direct electron transfer, engineering to be able to generate higher alkanes), the technology may find industrial application in both metabolic directions: methane to electricity, and electricity to liquefiable alkanes.

Specific applications for methane to electricity may be smaller power plants, e.g., next to biogas fermenters. Electricity to liquefiable alkanes is promising for storing excess from electricity overproduction (e.g., wind or sun), or for upgrading the $\mathrm{CO}_{2}$ from biogas plants, or by removing $\mathrm{CO}_{2}$ from other sources.

Although new and at a very early stage, the technology described seems the first step for catalytic alkane to electricity interconversion at low temperatures and constitutes the cornerstone of a sustainable flame-free-future (Kendall, 2000) for alkane fuels.

\section{AUTHOR CONTRIBUTIONS}

The author confirms being the sole contributor of this work and has approved it for publication.

Gold, S. (2012). “A low-temperature fuel cell technology for green energy, in Handbook of Climate Change Mitigation, eds W.-Y. Chen, J. Seiner, T. Suzuki and M. Lackner (New York, NY: Springer), 1657-1702.

Gorby, Y. A., Yanina, S., McLean, J. S., Rosso, K. M., Moyles, D., Dohnalkova, A., et al. (2006). Electrically conductive bacterial nanowires produced by Shewanella oneidensis strain MR-1 and other microorganisms. Proc. Natl. Acad. Sci. U. S. A. 103, 11358-11363. doi: 10.1073/pnas.06045 17103

Goyal, N., Zhou, Z., and Karimi, I. A. (2016). Metabolic processes of Methanococcus maripaludis and potential applications. Microb. Cell Fact. 15:107. doi: 10.1186/s12934-016-0500-0

Grisewood, M. J., Ferry, J. G., and Maranas, C. D. (2018). Computationally exploring and alleviating the kinetic bottlenecks of anaerobic methane oxidation. Front. Environ. Sci. 6, 1-18. doi: 10.3389/fenvs.2018. 00084

Hallam, S. J., Putnam, N., Preston, C. M., Detter, J. C., Rokhsar, D., Richardson, P. M., et al. (2004). Reverse methanogenesis: testing the hypothesis with environmental genomics. Science 305, 1457-1462. doi: 10.1126/science. 1100025

Huskinson, B., Marshak, M. P., Suh, C., Er, S., Gerhardt, M. R., Galvin, C. J., et al. (2014). A metal-free organic-inorganic aqueous flow battery. Nature 505, 195-200. doi: 10.1038/nature12909

Kendall, K. (2000). Hydrocarbon fuels - Hopes for a flame-free future. Nature 404, 233-235. doi: 10.1038/35005191 
Knittel, K., and Boetius, A. (2009). Anaerobic oxidation of methane: progress with an unknown process. Annu. Rev. Microbiol. 63, 311-334. doi: 10.1146/annurev.micro.61.080706.093130

Laso-Pérez, R., Wegener, G., Knittel, K., Widdel, F., Harding, K. J., Krukenberg, V., et al., (2016).Thermophilic archaea activate butane via alkyl-coenzyme M formation. Nature 539, 396-401. doi: 10.1038/nature20152

Logan, B. E., Hamelers, B., Rozendal, R., Schröder, U., Keller, J., Freguia, S., et al. (2006). Microbial fuel cells: methodology and technology. Environ. Sci. Technol. 40, 5181-5192. doi: 10.1021/es0605016

Lovley, D. R. (2012). Electromicrobiology. Annu. Rev. Microbiol. 66, 391-409. doi: 10.1146/annurev-micro-092611-150104

Lovley, D. R. (2017). Syntrophy goes electric: direct interspecies electron transfer. Annu. Rev. Microbiol. 71:annurev-micro-030117-020420. doi: 10.1146/annurev-micro-030117-020420

McAnulty, M. J., Poosarla, V. G., Kim, K.-Y., Jasso-Chávez, R., Logan, B. E., et al., Wood, T. K. (2017). Electricity from methane by reversing methanogenesis. Nat. Commun. 8:15419. doi: 10.1038/ncomms15419

McGlynn, S. E. (2017). Energy metabolism during anaerobic methane oxidation in ANME archaea. Microbes Environ. 32, 5-13. doi: 10.1264/jsme2.ME16166

McGlynn, S. E., Chadwick, G. L., Kempes, C. P. and Orphan, V. J. (2015).Single cell activity reveals direct electron transfer in methanotrophic consortia. Nature 526, 531-535. doi: 10.1038/nature 15512

Nayak, D. D., and Metcalf, W. W. (2017). Cas9-mediated genome editing in the methanogenic archaeon Methanosarcina acetivorans. Proc. Natl. Acad. Sci. U.S.A. 114, 2976-2981. doi: 10.1073/pnas.1618596114

O'Hayre, R., Cha, S.-W., Colella, W. G., and Prinz, F. B., (2016). “Chapter 13: fuel cell system design," in Fuel Cell Fundamentals (Wiley-Blackwell), 447-480.

Pachepsky, Y. A., Blaustein, R. A., Whelan, G. and Shelton, D. R. (2014). Comparing temperature effects on Escherichia coli, Salmonella, and Enterococcus survival in surface waters. Lett. Appl. Microbiol. 59, 278-283. doi: 10.1111/lam.12272

Pirbadian, S., and El-Naggar, M. Y. (2012). Multistep hopping and extracellular charge transfer in microbial redox chains. Phys. Chem. Chem. Phys. 14, 13802-13808. doi: 10.1039/c2cp41185g

Ritchie, M. E. (2018). Reaction and diffusion thermodynamics explain optimal temperatures of biochemical reactions. Sci. Rep. 8, 1-10. doi: 10.1038/s41598-018-28833-9
Rosso, K. M., Smith, D. M. A., Wang, Z. M., Ainsworth, C. C. and Fredrickson, J. K. (2004). Self-exchange electron transfer kinetics and reduction potentials for anthraquinone disulfonate. J. Phys. Chem. A 108, 3292-3303. doi: 10.1021/jp037134u

Scheller, S., Goenrich, M., Boecher, R., Thauer, R. K., and Jaun, B. (2010). The key nickel enzyme of methanogenesis catalyses the anaerobic oxidation of methane. Nature 465, 606-608. doi: 10.1038/nature09015

Scheller, S., Orphan, V. J., and Yu, H. (2018). Methane Oxidation Methods and Compositions. US Patent No 10011813.

Scheller, S., Yu, H., Chadwick, G. L., McGlynn, S. E., and Orphan, V. J. (2016).Artificial electron acceptors decouple archaeal methane oxidation from sulfate reduction. Science 351, 703-707. doi: 10.1126/science.aad7154

Schröder, U., and Harnisch, F. (2017). Life electric-nature as a blueprint for the development of microbial electrochemical technologies. Joule 1, 244-252. doi: 10.1016/j.joule.2017.07.010

Thauer, R. K., Kaster, A.-K., Seedorf, H., Buckel, W., and Hedderich, R. (2008). Methanogenic archaea: ecologically relevant differences in energy conservation. Nat. Rev. Microbiol. 6, 579-591. doi: 10.1038/nrmicro1931

Timmers, P. H. A., Welte, C. U., Koehorst J. J., Plugge C. M., Jetten, M. S. M., and Stams A. J. M. (2017). Reverse methanogenesis and respiration in methanotrophic archaea. Archaea 2017:22. doi: 10.1155/2017/1654237

Wegener, G., Krukenberg, V., Riedel, D., Tegetmeyer, H. E. and Boetius, A. (2015) Intercellular wiring enables electron transfer between methanotrophic archaea and bacteria. Nature 526, 587-590. doi: 10.1038/nature 15733

Yan, Z., Joshi, P., Gorski, C. A., and Ferry, J. G. (2018). A biochemical framework for anaerobic oxidation of methane driven by $\mathrm{Fe}$ (III)-dependent respiration. Nat. Commun. 9, 1-9. doi: 10.1038/s41467-018-04097-9

Conflict of Interest Statement: SS is inventor of a patent filed by California Institute of Technology, Pasadena, CA (US).

Copyright (C) 2018 Scheller. This is an open-access article distributed under the terms of the Creative Commons Attribution License (CC BY). The use, distribution or reproduction in other forums is permitted, provided the original author $(s)$ and the copyright owner(s) are credited and that the original publication in this journal is cited, in accordance with accepted academic practice. No use, distribution or reproduction is permitted which does not comply with these terms. 